\title{
Effect of Various Tillage Practices on Soil Physical Properties
}

\author{
Sushil Kumar*, Mukesh Jain, Vijaya Rani, Anil Kumar, Vinod Kumar and Naresh \\ Department of Farm Machinery and Power Engineering, CCS Haryana Agricultural \\ University, Hisar-125004, Haryana, India \\ *Corresponding author
}

\begin{abstract}
A B S T R A C T
Different types of tillage systems have different tillage depths and capacity to change soil physical properties that affect the crop yield and quality. Important soil physical properties such as bulk density, penetration resistance, water infiltration, hydraulic conductivity and

\begin{tabular}{|l|}
\hline Key w or d s \\
Tillage, No tillage, \\
Rotavator, \\
Subsoiler, \\
Compaction
\end{tabular}
soil compaction are affected by tillage. A study on "Effect of various tillage methods on soil compaction" was conducted during Rabi season of year 2013-14 at village Ladwa, Hisar, Haryana (India). Experiment compares the soil parameters for six tillage treatments no-tillage $\left(T_{1}\right)$, tillage with rotavator $\left(T_{2}\right)$, disc harrow $\left(T_{3}\right)$, Rotavator + subsoiler $\left(T_{4}\right)$, disc harrow + subsoiler $\left(\mathrm{T}_{5}\right)$, power harrow $\left(\mathrm{T}_{6}\right)$. The soil parameters like soil resistance, bulk density, moisture content and water infiltration rate were studied.Maximum soil resistance was found in zero tillage followed by disc harrow up to $150 \mathrm{~mm}$ soil depth. Minimum soil resistance was found in rotavator immediately after the tillage treatment. However, the soil resistance increased steadily after 30 DAS and 90 DAS and it almost approached the initial soil resistance level as it was before tillage after 90 days of sowing. Significant changes in bulk density also have been observed in treatment rotavator + subsoiler which substantiates the fact that this treatment has the minimum soil resistance. Minimum moisture loss has been registered in treatment no tillage and maximum was in power harrow. Water infiltration rate before the tillage treatment was $1.13 \mathrm{~cm} /$ minute in all the treatments and after the treatments the infiltration rate ranged between 1.19 to 2.72 $\mathrm{cm} /$ minute.
\end{abstract}

\section{Introduction}

The prime necessity of tillage is to prepare the land or the seedbed where the plants can easily grow. In the early age, it was not possible to till vast area of land to desirable depth by hand tools. Following the industrial revolution in the nineteenth century, agricultural machinery and tractors became available for tillage operations. Tilling the fields hinders or slowdown the growth of weeds and improve crops' competition against weeds. Moreover, tillage loosens the compacted layers. Different types of tillage systems have different tillage depths and capacity to change soil physical and chemical properties that affect the crop yield and quality (Strudley et al., 2008).

In many ecological zones and on different soil types, crop response to tillage and indeed the economic viability of tillage systems are still subjects of investigation (Adamu and 
Abdulrazaq, 2004). Soil structural modification through tillage is aimed at optimizing soil conditions for seed germination, seedling emergence and growth. In general, any good tillage system should provide good soil tilth, improve soil water infiltration and retention, reduce weed competition, minimize soil erosion, control infestation of pests, encourage biological activities of soil microorganisms and recycle soil organic matter through residue management.

Soil structure is important because it determines the ability of a soil to hold and conduct water, nutrients, and air necessary for plant root activity. Although much research has been conducted on soil compaction and its effects on yield, it is difficult to estimate an economic impact because fields vary in soil types, crop rotations, and weather conditions.

\section{Materials and Methods}

The study was carried out at farmer's field of village Ladwa, Hisar, Haryana (India). Six tillage treatments no-tillage $\left(\mathrm{T}_{1}\right)$, rotavator $\left(\mathrm{T}_{2}\right)$, disc harrow $\left(\mathrm{T}_{3}\right)$, Rotavator + subsoiler $\left(\mathrm{T}_{4}\right)$, disc harrow + subsoiler $\left(\mathrm{T}_{5}\right)$, power harrow $\left(\mathrm{T}_{6}\right)$ were conducted during the study. The soil parameters like soil resistance, bulk density, moisture content and water infiltration rate were calculated. Soil cone index/soil resistance was calculated with the help of electronic cone penetrometer (model- 58020 Sensorika Australia).

Bulk density of soil was determined by core cutter sampling method. A core cutter of 1000 cc was taken and soil samples were taken from different locations. The samples of the soil from different locations at the depth of 0-5 $\mathrm{cm}, 5-10 \mathrm{~cm}$ and $10-15 \mathrm{~cm}$ in the field were taken and moisture content was determined by oven drying method. Double ring infiltrometer was used to calculate water infiltration rate.

\section{Results and Discussion}

The results of soil resistance $(\mathrm{kPa})$ at different depth $(\mathrm{mm})$ of soil, before tillage, no-tillage $\left(\mathrm{T}_{1}\right)$, rotavator $\left(\mathrm{T}_{2}\right)$, disc harrow $\left(\mathrm{T}_{3}\right)$, Rotavator + subsoiler $\left(\mathrm{T}_{4}\right)$, disc harrow + subsoiler $\left(\mathrm{T}_{5}\right)$, power harrow $\left(\mathrm{T}_{6}\right)$ are graphically depicted in Figure 1. Soil resistance in treatment $T_{1}$ (no tillage) was found similar to the soil resistance before any tillage operation. However, significant changes in soil resistance have been recorded after using rotavator $\left(\mathrm{T}_{2}\right)$ up to the depth of $100 \mathrm{~mm}$, up to $150 \mathrm{~mm}$ after using disc harrow $\left(\mathrm{T}_{3}\right)$, up to $250 \mathrm{~mm}$ after using rotavator + subsoiler $\left(\mathrm{T}_{4}\right)$ and disc harrow + subsoiler $\left(\mathrm{T}_{5}\right)$ and up to $200 \mathrm{~mm}$ after using power harrow $\left(\mathrm{T}_{6}\right)$. However, the soil resistance approached the same level as it had been before the tillage after the soil strata where the implement cannot reach. Kumar et al., (2012) also found higher soil resistance in no tillage as compared to conventional tillage. Elhers et al., (1983) also concluded similar values of soil resistance for no tillage and conventional tillage.

As shown in Figure 2, soil resistance level almost approached the initial soil resistance level as it was before tillage after 90 days of sowing. Prem kishor et al., (2013) also observed that most tillage practices have pronounced effects on soil hydraulic properties, infiltration rates, percolation, leaching, and oxygen diffusion rate immediately following non-tillage application, but these effects can diminish rapidly.

Bulk density $\left(\mathrm{g} \mathrm{cc}^{-1}\right)$ of soil was recorded at two depths of soil $10 \mathrm{~cm}$ and $20 \mathrm{~cm}$ before and after the tillage treatments. As shown in table 1 , at $10 \mathrm{~cm}$ soil depth bulk density was $1.48 \mathrm{~g}$ $\mathrm{cc}^{-1}$ before treatments and after treatment ranged between 1.43 to $1.48 \mathrm{~g} \mathrm{cc}^{-1}$. Higher reduction in bulk density was observed in treatment $\mathrm{T}_{4}$ (rotavator + subsoiler) and treatment $\mathrm{T}_{5}$ (disc harrow + subsoiler). 


\section{Table.1 Bulk density $\left(\mathrm{g} \mathrm{cc}^{-1}\right)$ of soil}

\begin{tabular}{|c|c|c|c|c|c|c|}
\hline \multicolumn{7}{|c|}{ Bulk Density (g cc ce $^{-1}$} \\
\hline & \multicolumn{3}{|c|}{$10 \mathrm{~cm}$ Soil Depth } & \multicolumn{3}{|c|}{$20 \mathrm{~cm}$ Soil Depth } \\
\hline Treatment & Before & After & Mean & Before & After & Mean \\
\hline No tillage $\left(T_{1}\right)$ & 1.48 & 1.48 & $1.48^{\mathrm{c}}$ & 1.51 & 1.51 & $1.51^{\mathrm{c}}$ \\
\hline Rotavator $\left(\mathrm{T}_{2}\right)$ & 1.48 & 1.44 & $1.46^{\mathrm{a}}$ & 1.51 & 1.48 & $1.49^{\mathrm{a}}$ \\
\hline Disc harrow $\left(\mathrm{T}_{\mathbf{3}}\right)$ & 1.48 & 1.47 & $1.47^{b}$ & 1.51 & 1.5 & $1.51^{\mathrm{c}}$ \\
\hline Rotavator + subsoiler $\left(\mathrm{T}_{4}\right)$ & 1.48 & 1.43 & $1.46^{\mathrm{a}}$ & 1.51 & 1.47 & $1.49^{\mathrm{a}}$ \\
\hline Disc harrow + subsoiler $\left(T_{5}\right)$ & 1.48 & 1.45 & $1.46^{\mathrm{a}}$ & 1.51 & 1.48 & $1.5^{\mathrm{b}}$ \\
\hline Power harrow $\left(\mathrm{T}_{6}\right)$ & 1.48 & 1.45 & $1.47^{b}$ & 1.51 & 1.4 & $1.5^{\mathrm{b}}$ \\
\hline \multirow[t]{5}{*}{ Mean } & 1.48 & 1.45 & & 1.51 & 1.49 & \\
\hline & \multicolumn{2}{|c|}{ Factor } & C.D. & \multicolumn{2}{|c|}{ Factor } & C.D. \\
\hline & \multicolumn{2}{|c|}{ Tillage time (A) } & 0.004 & \multicolumn{2}{|c|}{ Tillage time (A) } & 0.004 \\
\hline & \multicolumn{2}{|c|}{ Treatment (B) } & 0.006 & \multicolumn{2}{|c|}{ Treatment (B) } & 0.008 \\
\hline & \multicolumn{2}{|c|}{$\mathrm{A} * \mathrm{~B}$} & 0.009 & \multicolumn{2}{|c|}{$\mathrm{A}^{*} \mathrm{~B}$} & 0.011 \\
\hline
\end{tabular}

\begin{tabular}{|c|c|c|c|c|c|c|c|c|c|}
\hline \multirow{2}{*}{\multicolumn{10}{|c|}{$\begin{array}{r}\text { Table.2 Moisture content of soil at } \\
\text { Moisture Content }\end{array}$}} \\
\hline \multicolumn{8}{|c|}{ Moisture Content } & & \\
\hline & \multicolumn{3}{|c|}{$10 \mathrm{~cm}$ Soil Depth } & \multicolumn{3}{|c|}{$20 \mathrm{~cm}$ Soil Depth } & \multicolumn{3}{|c|}{$30 \mathrm{~cm}$ Soil Depth } \\
\hline Treatment & Before & After & Mean & Before & After & Mean & Before & After & Mean \\
\hline $\begin{array}{l}\text { No tillage } \\
\left(\mathrm{T}_{1}\right)\end{array}$ & 13.30 & 13.30 & $13.30^{\mathrm{a}}$ & 15.31 & 15.30 & $15.31^{\mathrm{a}}$ & 17.32 & 17.32 & $17.32^{\mathrm{a}}$ \\
\hline $\begin{array}{c}\text { Rotavator } \\
\left(\mathrm{T}_{2}\right)\end{array}$ & 13.36 & 13.29 & $13.33^{\mathrm{bc}}$ & 15.36 & 15.29 & $15.32^{\mathrm{ab}}$ & 17.36 & 17.29 & $17.33^{\mathrm{ab}}$ \\
\hline $\begin{array}{c}\text { Disc } \\
\text { harrow } \\
\left(\mathrm{T}_{\mathbf{3}}\right)\end{array}$ & 13.38 & 13.34 & $13.36^{\mathrm{c}}$ & 15.37 & 15.34 & $15.35^{\mathrm{bc}}$ & 17.38 & 17.36 & $17.37^{\mathrm{c}}$ \\
\hline $\begin{array}{c}\text { Rotavator } \\
+ \text { subsoiler } \\
\left(\mathrm{T}_{4}\right) \\
\end{array}$ & 13.38 & 13.30 & $13.34^{\mathrm{bc}}$ & 15.37 & 15.31 & $15.34^{\mathrm{bc}}$ & 17.37 & 17.31 & $17.34^{\mathrm{ab}}$ \\
\hline $\begin{array}{c}\text { Disc } \\
\text { harrow }+ \\
\text { subsoiler } \\
\left(\mathrm{T}_{5}\right) \\
\end{array}$ & 13.37 & 13.30 & $13.34^{\mathrm{bc}}$ & 15.37 & 15.30 & $15.34^{b c}$ & 17.36 & 17.30 & $17.33^{\mathrm{ab}}$ \\
\hline $\begin{array}{c}\text { Power } \\
\text { harrow } \\
\left(\mathrm{T}_{6}\right) \\
\end{array}$ & 13.36 & 13.28 & $13.32^{\mathrm{AB}}$ & 15.36 & 15.28 & $15.32^{\mathrm{ab}}$ & 17.36 & 17.28 & $17.32^{\mathrm{a}}$ \\
\hline \multirow[t]{5}{*}{ Mean } & 13.36 & 13.30 & & 15.36 & 15.30 & & 17.36 & 17.31 & \\
\hline & \multicolumn{2}{|c|}{ Factor } & C.D. & \multicolumn{2}{|c|}{ Factor } & C.D. & \multicolumn{2}{|c|}{ Factor } & C.D. \\
\hline & \multicolumn{2}{|c|}{$\begin{array}{l}\text { Tillage time } \\
\text { (A) }\end{array}$} & 0.014 & \multicolumn{2}{|c|}{$\begin{array}{l}\text { Tillage time } \\
\text { (A) }\end{array}$} & 0.014 & \multicolumn{2}{|c|}{$\begin{array}{l}\text { Tillage time } \\
\text { (A) }\end{array}$} & 0.016 \\
\hline & \multicolumn{2}{|c|}{ Treatment (B) } & 0.024 & \multicolumn{2}{|c|}{ Treatment (B) } & 0.024 & \multicolumn{2}{|c|}{ Treatment (B) } & 0.028 \\
\hline & \multicolumn{2}{|c|}{$A * B$} & N/A & \multicolumn{2}{|c|}{$\mathrm{A} * \mathrm{~B}$} & $\mathrm{~N} / \mathrm{A}$ & \multicolumn{2}{|c|}{$\mathrm{A} * \mathrm{~B}$} & 0.039 \\
\hline
\end{tabular}




\section{Table.3 Water infiltration rate}

\begin{tabular}{|c|c|c|c|}
\hline \multicolumn{4}{|c|}{ Water Infiltration Rate (cm/minute) } \\
\hline Treatment & Before & After & Mean \\
\hline No tillage $\left(\mathrm{T}_{1}\right)$ & 1.13 & 1.19 & $1.16^{\mathrm{a}}$ \\
\hline Rotavator $\left(\mathbf{T}_{2}\right)$ & 1.13 & 2.44 & $1.78^{\mathrm{b}}$ \\
\hline Disc harrow $\left(\mathrm{T}_{3}\right)$ & 1.13 & 2.61 & $1.87^{\mathrm{c}}$ \\
\hline Rotavator + subsoiler $\left(\mathbf{T}_{4}\right)$ & 1.13 & 2.67 & $1.90^{\mathrm{d}}$ \\
\hline Disc harrow + subsoiler $\left(\mathbf{T}_{5}\right)$ & 1.13 & 2.72 & $1.92^{\mathrm{d}}$ \\
\hline Power harrow $\left(\mathrm{T}_{6}\right)$ & 1.13 & 2.58 & $1.85^{\mathrm{c}}$ \\
\hline Mean & 1.13 & 2.37 & \\
\hline & \multicolumn{2}{|c|}{ Factor } & C.D. \\
\hline & \multicolumn{2}{|c|}{ Treatment(A) } & 0.015 \\
\hline & \multicolumn{2}{|c|}{ Tillage time(B) } & 0.026 \\
\hline & \multicolumn{2}{|c|}{$A * B$} & 0.037 \\
\hline
\end{tabular}

Fig.1 Soil resistance $(\mathrm{kPa})$ at different depth $(\mathrm{mm})$ of soil at 0 DAS

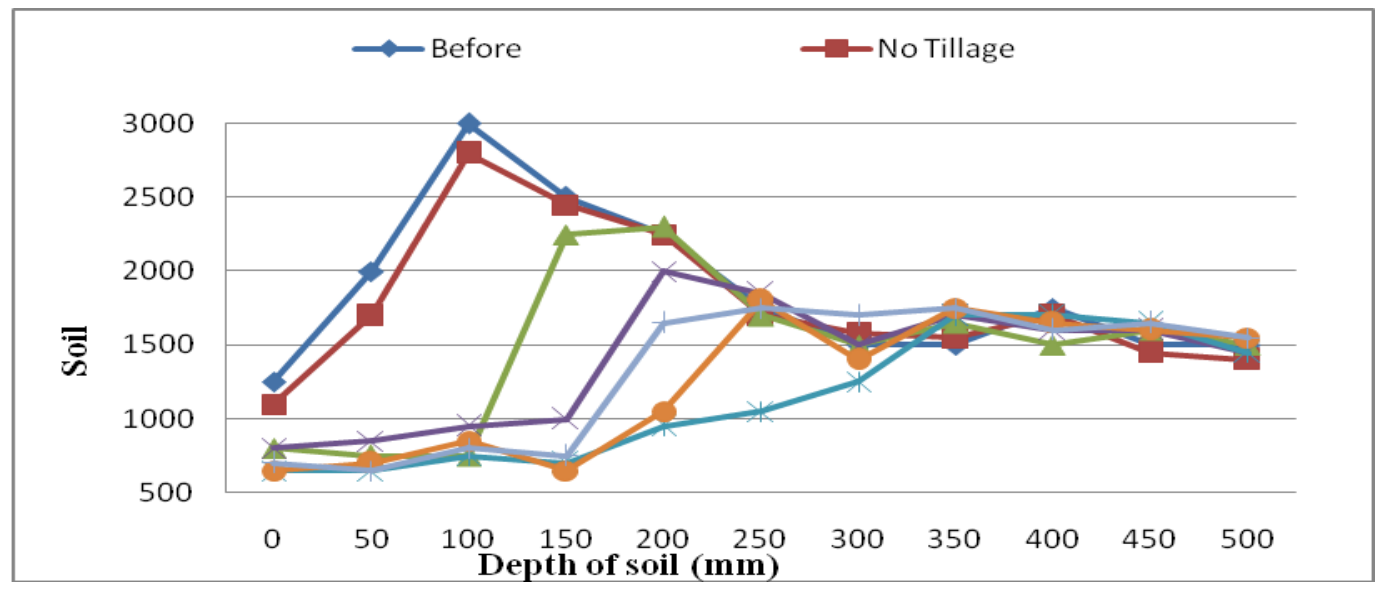

Fig.2 Soil resistance $(\mathrm{kPa})$ at different depth $(\mathrm{mm})$ of soil at 90 DAS for all treatment

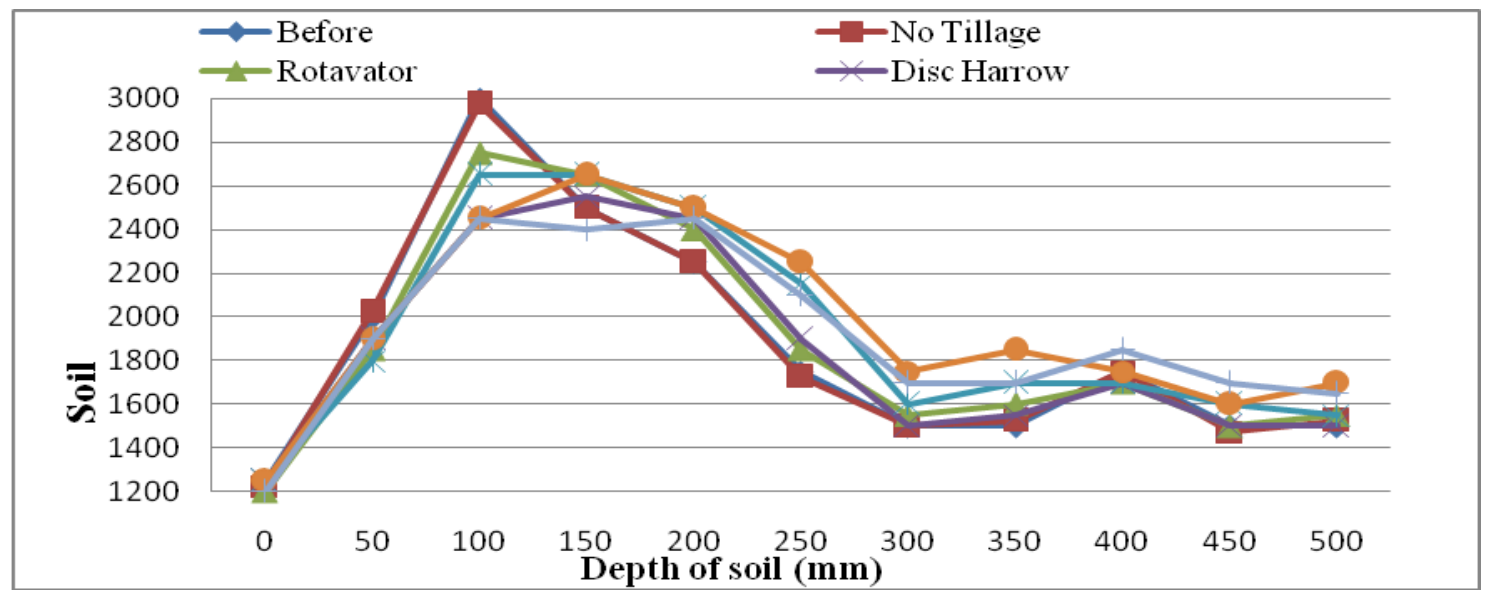


Minimum change was recorded in the treatment $\mathrm{T}_{1}$ (no tillage). Almost similar trend was found at $20 \mathrm{~cm}$ soil depth. At $20 \mathrm{~cm}$ soil depth the soil bulk density before the treatment was 1.51 and after the treatment it ranged between 1.40 to $1.51 \mathrm{~g} \mathrm{cc}^{-1}$. Maximum reduction in soil bulk density was found in treatment $\mathrm{T}_{4}$ (rotavator + subsoiler) and minimum reduction was registered in treatment $\mathrm{T}_{1}$ (no tillage). Bhattachariya et al., (2008) also reported a decrease in bulk density with increase in tillage intensity.

As shown in Table 2, at $10 \mathrm{~cm}$ soil depth, minimum moisture loss has been registered in treatment $\mathrm{T}_{1}$ (no tillage) and maximum was in $\mathrm{T}_{6}$ (power harrow) and higher loss in moisture content was recorded in treatment $\mathrm{T}_{3}$ (disc harrow). At $20 \mathrm{~cm}$ soil depth, minimum moisture loss was recorded in treatment $T_{1}$ (no tillage) followed by treatment $\mathrm{T}_{6}$ (power harrow) and treatment $\mathrm{T}_{2}$ (rotavator). At 30 $\mathrm{cm}$ soil depth, minimum moisture loss was found in treatment $T_{1}$ (no tillage) and treatment $\mathrm{T}_{6}$ (power harrow), Maximum loss was recorded in treatment $\mathrm{T}_{3}$ (disc harrow). Nosrat Allah Heidarpur et al., (2011) also reported that there was significant loss in soil moisture content amongst different tillage methods.

Water infiltration rate before the tillage treatment was $1.13 \mathrm{~cm} /$ minute in all the treatments and after the treatments, the infiltration rate ranged between 1.19 to 2.72 $\mathrm{cm} /$ minute. Highest infiltration rate was found in treatment $\mathrm{T}_{4}$ (rotavator + subsoiler) and $\mathrm{T}_{5}$ (disc harrow + subsoiler) and minimum infiltration rate was found in treatment $\mathrm{T}_{1}$ (no tillage) (Table 3).

No change in soil resistance was observed before and after no tillage treatment. However, significant changes in soil resistance have been recorded in all the other tillage treatments i.e. rotavator $\left(\mathrm{T}_{2}\right)$, disc harrow $\left(\mathrm{T}_{3}\right)$, rotavator + subsoiler $\left(\mathrm{T}_{4}\right)$, disc harrow + subsoiler $\left(\mathrm{T}_{5}\right)$ and power harrow $\left(\mathrm{T}_{6}\right)$. Maximum soil resistance was found in zero tillage $\left(\mathrm{T}_{1}\right)$ followed by disc harrow $\left(\mathrm{T}_{3}\right)$ up to $150 \mathrm{~mm}$ soil depth. Minimum soil resistance was found in rotavator immediately after the tillage treatment. However, the soil resistance increased steadily after 30 DAS and 90 DAS and it almost approached the initial soil resistance level as it was before tillage after 90 DAS. Significant changes in bulk density have also been observed in treatment rotavator + subsoiler $\left(\mathrm{T}_{4}\right)$ which substantiates the fact that this treatment has the minimum soil resistance. Up to $20 \mathrm{~cm}$ depth soil profile, maximum moisture loss has been registered in disc harrow $\left(\mathrm{T}_{3}\right)$ followed by the rotavator $\left(\mathrm{T}_{2}\right)$. The reason is obvious as the soil profile is open to evaporation. However, at $30 \mathrm{~cm}$ depth, the moisture loss is maximum in treatments where subsoiler have been used.Higher infiltration rate was found in treatment $\mathrm{T}_{4}$ (rotavator + subsoiler) and $\mathrm{T}_{5}$ (disc harrow + subsoiler) because the subsoiler does deeper cultivation and thus break the capillary which results in high water infiltration rate. Minimum water infiltration rate was found in treatment $\mathrm{T}_{1}$ (no tillage).

\section{References}

Adamu, S., and Abdulrazaq, H. 2004. Effect of tillage on the growth and yield of groundnut (Arachis hypogea) at Bauchi in the northern guinea savannah zone of Nigeria. International Journal of Food and Agricultural Research. 1(142): 4853

Bhattacharya, R., Kundu, S.C., Panday, K.P., and Gupta, H.S. 2008. Tillage and irrigation effect on crop yield and soil properties under the rice-wheat in the Indian Himalayas. Agricultural water management. 95: 993-1002

Ehlers, W., Kopke, U., Hesse, F., and Bohm, W. 1983. Penetration resistance and 
root growth of oats in tilled and untilled loess soil. Soil \& Tillage Research. 3: 261-275.

Kishor, P., Ghosh, A.K., and Claramma, P.V. 2013. Influence of tillage on soil physical environment. International Journal of Agronomy and plant production. 4(10): 2592-97.

Kumar, A., Chen, Y., Sadek, A. and Rahman, S., 2012. Soil cone index in relation to soil texture, moisture content and bulk density for no tillage and conventional tillage. The CIGR Journal. 14(1): 26-37
Nosrat, A.H., Moslem, A., and Behroz, V. 2011. Effects of tillage on bulk density and soil moisture content in wheatfallow rotation under dry conditions. Scientific Research and Essays, 6(17): 3668-74

Strudley, M.W., and Green, T.R. 2008. Tillage effect on soil hydraulic properties in space and time: State of the science. Soil and Tillage research. 99(1): 4-48.

\section{How to cite this article:}

Sushil Kumar, Mukesh Jain, Vijaya Rani, Anil Kumar, Vinod Kumar and Naresh. 2018. Effect of Various Tillage Practices on Soil Physical Properties. Int.J.Curr.Microbiol.App.Sci. 7(03): 1591-1596. doi: https://doi.org/10.20546/ijcmas.2018.703.191 